Geliş Tarihi:

29.08.2020

Kabul Tarihi:

15.04.2021

Yayımlanma Tarihi:

25.06.2021
Kaynakça Gösterimi: Bilgili, M. Y. (2021). Sıfır atık yaklaşımının kökenleri ve günümüzdeki anlamı. İstanbul Ticaret Üniversitesi Sosyal Bilimler Dergisi, 20(40), 683-703. doi: 10.46928/iticusbe.787711

\title{
SIFIR ATIK YAKLAŞIMININ KÖKENLERİ VE GÜNÜMÜZDEKİ ANLAMI
}

\section{Derleme}

Muhammed Yunus Bilgili (iD) $\mathrm{p}$

Sorumlu Yazar (Correspondence)

Karadeniz Teknik Üniversitesi

mybilgili@ktu.edu.tr

Muhammed Yunus Bilgili, Karadeniz Teknik Üniversitesi Kamu Yönetimi Bölümü Öğretim Üyesidir. Yerel yönetimler, kent ekonomisi ve çevre yönetimi alanlarında dersler vermekte ve çevre yönetimi ve politikası, atık yönetimi ve karşılaştırmalı yerel yönetimler alanında araştırmalar yapmaktadır. 


\title{
SIFIR ATIK YAKLAŞIMININ KÖKENLERİ VE GÜNÜMÜZDEKİ ANLAMI
}

\author{
Muhammed Yunus Bilgili \\ mybilgili@ktu.edu.tr
}

\section{ÖZET}

Atık sorunuyla mücadele edebilmek için günümüzde sıfır atık olarak nitelendirilen atık yönetim anlayışının temel düşünceleri, doğal çevrimler ve döngüsel ekonomi modelinin dayanak noktalarıyla büyük oranda benzerlik göstermektedir.

Amaç: Bu çalışmanın amacı, sıfır atık yaklaşımının, geçmişten günümüze geçirdiği dönüşümleri atık sorunu, atıkların yönetilmesi gerekliliği, doğrusal ve döngüsel ekonomi bağlamında ele alınması ve kavramın günümüzdeki anlamının incelenmesidir.

Yöntem: Literatür araştırması yöntemine dayanan bu çalışmada, kaynak taraması "Science Direct", "Wiley", “Taylor and Francis”, “ JStor”, "Web of Science” ve "Google Scholar” veri tabanlarında, "sıfır atık yaklaşımı”, "sıfır atık yaklaşımının tarihi", "sıfır atık hiyerarşisi” ve "döngüsel ekonomi ve sıfır atık" gibi anahtar kavramlar girilerek gerçekleştirilmiştir.

Bulgular: Yapılan araştırmalar sonucunda, sıfır atık yaklaşımının temel mantığı ile uyumlu düşüncelere 19. yüzyılda rastlanılmasına rağmen, kavramın ilk kez 1970'li yıllarda kullanıldığı, günümüzdeki anlamının ise daha çok döngüsel ekonomi ve sıfır atık hiyerarşisi kapsamında ele alındığı tespit edilmiştir. Ayrıca sıfır atık yaklaşımının öncelikli uygulamalarının sıfır atık ürün tasarımı, atık azaltımı ve önleme ile yeniden kullanım olduğu sonucuna ulaşılmıştır.

Özgünlük: Çalışmanın özgün yanı, sıfır atık yaklaşımının ortaya çıkışı, tarihsel dönüşüm süreci ve günümüzdeki anlamını Türk çevre literatüründe detaylı bir şekilde ele almasıdır.

Anahtar Kelimeler: Atık, Atık Sorunu, Atık Yönetimi, Sıfır Atık, Sıfır Atık Hiyerarşisi

JEL Sinıflandırması: Q53 


\section{THE ORIGINS AND CURRENT MEANING OF ZERO WASTE APPROACH}

\section{ABSTRACT}

To struggle with the waste problem, the main thoughts of the waste management approach, which is considered zero waste at present, are largely analogous to the bases of the natural cycles and circular economy model.

Purpose: This study aims to examine the transformations of the zero waste approach from the past to the present in the context of the waste problem, the necessity of waste management, linear and circular economy and to examine the current meaning of the concept.

Method: In this study, which based on literature research method, the literature review was carried out in "Science Direct”, "Wiley”, “Taylor and Francis”, “JStor”, "Web of Science”, and "Google Scholar” databases to "zero waste approach", "history of zero waste approach”, "zero waste hierarchy”, and "circular economy and zero waste" keywords.

Findings: As a result of the research, it has been determined that although the thoughts compatible with the basic idea of the zero waste approach were encountered in the 19th century, the concept was first used in the 1970s, and its current meaning is mostly addressed in the context of the circular economy and zero waste hierarchy. Also, it was concluded that the priority applications of the zero waste approach are zero waste product design, waste reduction/prevention, and reuse.

Originality: The authenticity aspect of the study is to explain the occurrence of the zero waste approach, the historical transformation process, and the current meaning in Turkish environmental literature in detail.

Keywords: Waste, Waste Issue, Waste Management, Zero Waste, Zero Waste Hierarchy

JEL Classification: Q53 


\section{GİRIŞ}

Kentleşme, sanayileşme, nüfus artışı ve doğrusal ekonomi anlayışını temel alan üretim ve tüketim süreçleri, büyük miktarlarda atık ortaya çıkmasına neden olmaktadır. Bu atıkların çevre ve insan sağlı̆̆ını riske atmadan yönetilmesi, doğayla uyumlu atık yönetim sistemlerinin geliştirilmesini gerektirmektedir. Atıkların doğayla uyumlu bir şekilde yönetilmesine ilişkin arayışlar, insanları bizzat doğanın kendisine yöneltmiştir. Doğal süreçler incelendiğinde, doğada atık üretilmemesinin temelinde, çevresel bir unsur tarafından üretilen atı̆̆ın, bir diğer çevresel unsurun girdisi olduğu tekrardan öğrenilmiştir. Bu öğrenme süreci, atık yönetiminde doğrusal ekonomi anlayışının bırakılması ve döngüsel ekonomi yaklaşımının benimsenmesinin atık sorununu çözebileceğine ilişkin bir inancın oluşmasını sağlamıştır. 20. ve 21. yüzyılın en önemli sorunlarından bir olan atık konusunun çözüme kavuşturulmasında, doğal süreçlere dönüş ve döngüsel ekonomi anlayışının etkisiyle, sıfır atık olarak nitelenen atık yönetim stratejisi ortaya çıkmıştır.

Kavram olarak sıfır atık, 1970'li yıllarda kullanılmış olmasına rağmen (Nizar vd., 2018: 3; Warner vd., 2015: 14), söz konusu atık yönetim stratejisinin temel mantığıyla benzer düşüncelere 19. yüzyılda rastlamak mümkündür. Bu çalışmanın amacı, atıkların kaynakta önlenmesi ve azaltılması, yeniden kullanılması, geri dönüştürülmesi ve kazanılması, depolama ve yakma gibi çevre ve insan sağlığını riske atan yöntemlere başvurulmadan yönetilmesi olarak nitelenen sıfır atık yaklaşımının tarihsel gelişim sürecinin ve günümüzdeki anlamının açıklanmasıdır.

Türkiye'de sıfır atık yaklaşımı ile ilgili yapılan çalışmalarda, kavramın ortaya çıkışı ve geçirdiği tarihsel dönüşümler ile günümüzdeki anlamını detaylı bir şekilde ele alan çalışma sayısının az olduğu belirtilmelidir. Bu bağlamda çalışmanın özgün yanı, Türkiye'de sıfır atık yaklaşımının kökenleri, tarihsel gelişim süreci ve günümüzdeki anlamını detaylı bir şekilde ele almasıdır.

Literatür araştırmasına dayanan bu çalışmada ilk önce, atık, atıkların mevcut durumu ve yönetimi, doğrusal ve döngüsel ekonomi ile atık üretimi arasındaki ilişki gibi kavramsal açıklamalara yer verilmiş̧ir. Sonra, sıfır atık yaklaşımını ortaya çıkaran nedenler ele alınmış, ardından kavramın tarihsel gelişim süreci detaylı bir şekilde incelenmiştir. Son olarak, sıfır atık yaklaşımının günümüzdeki anlamı, döngüsel ve doğrusal ekonomi ile sıfır atık hiyerarşisi bağlamında tartışılmıştır. 


\section{YÖNTEM VE LİTERATÜR ÖZETİ}

Sıfır atık yaklaşımın tarihsel süreç içerisindeki dönüşümü ile günümüzdeki anlamını ele alan bu çalışma literatür araştırmasına dayanmaktadır. Literatür araştırması yapılırken öncelikle sıfır atık yaklaşımının ne anlama geldiğinin saptanmasına amacı ile ulusal ve uluslararası kaynaklara ilişkin tarama yapılmıştır.

Kaynak taramas1, "Science Direct (https://www.sciencedirect.com/)", "Wiley (https://onlinelibrary.wiley.com/)", “Taylor and Francis (https://www.tandfonline.com/)", "J Stor (https://www.jstor.org/)", "Web of Science (www.webofknowledge.com)” ve "Google Scholar (https://scholar.google.com/) veri tabanlarında gerçekleştirilmiştir.

Kaynaklara ulaşabilmek amacıyla ilk önce "sıfır atık (zero waste)", "sıfır atık yaklaşımı (zero waste approach)", "sıfır atık yönetimi (zero waste management)", "sıfır atık yaklaşımının tarihi (history of zero waste approach)" ve "sıfır atık yaklaşımının kökenleri (roots of zero waste approach)" anahtar kelimeleri ilgili veri tabanlarında araştırılmıştır. Ayeleru vd. (2018), Song vd. (2015) ve Uz Zaman (2015)'in, sıfır atık yaklaşımı ile ilgili çalışmalarında, atık sorunu ve yönetimi bağlamında birtakım tartışmalar yaptığının tespit edilmesi üzerine, çalışma kapsamında yapılan literatür taramasının kapsamı genişletilmiştir. Başka bir deyişle, tespit edilen kaynaklardan farklı kaynaklara ulaşılmasına dayanan bir kartopu metodu uygulanmıştır. Bu çerçevede söz konusu veri tabanlarında "atık kavramı (concept of waste)", "atık sorunu (waste problem/issue)" ve "atık yönetimi (waste management)" anahtar kavramları araştırılmıştır.

Sıfır atık yaklaşımının ortaya çıkışında, Murray (2002) toplam kalite yönetimi anlayışını, Curran ve Williams (2012), Song vd. (2015) ve Lehmann (2011) yaklaşımın döngüsel ekonomi ile olan bağlantılarını ve Connett ve Sheehan (2001) ise yaklaşımın ortaya çıkışında atıkların yakılarak bertaraf edilmesine karşı başlatılan toplumsal hareketlerin etkisini ön planda tutmaktadır. $\mathrm{Bu}$ doğrultuda, sıfır atık yaklaşımının tarihsel kökenlerine ilişkin araştırmalar, "toplam kalite yönetimi ve sıfır atık (total quality management and zero waste)", döngüsel ekonomi ve sıfır atık (circular economy and zero waste) ve "atıkların yakılmasına karşı yürütülen toplumsal hareketler (antiincineration movement)" bağlamında yapılımıştır. Bununla beraber, Connett (2013)'te yer alan "atığın kadar öde (pay as you throw)" ve "entegre katı atık yönetimi (integrated solid waste management)" gibi çeşitli uygulamaların sıfır atık yaklaşımının ortaya çıkışındaki etkileri de dikkate alınmıştır.

Çalışmanın bir diğer araştırma konusu olan sıfır atık yaklaşımının günümüzdeki anlamının tespit edilmesine yönelik tarama, veri tabanlarında "sıfır atık (zero waste)" anahtar kelimesi girilerek başlatılmış ve kaynaklar tarih açısından en yeniye göre sıralanarak incelenmiştir. İncelemeler sonucunda, ZWIA (2018) ve Simon (2019)'un atık hiyerarşilerini öne çıkardığ 1 , ayrıca döngüsel ekonomi anlayışının sıfır atık yaklaşımının güncel anlamında da önemli bir payının olduğu tespit edilmiştir. Bu çerçevede, döngüsel ekonomi anlayışının yanında, sıfır atık hiyerarşilerinin tespit edilmesi amacıyla veri tabanlarında "sıfır atık hiyerarşisi (zero waste hierarchy)" anahtar kavramına 
ilişkin araştırmalar gerçekleştirilmiş ve kavramın günümüzdeki anlamı döngüsel ekonomi ve sıfır atık hiyerarşisi kapsamında incelenmiştir.

\section{KAVRAMSAL OLARAK ATIK, ATIK SORUNU VE YÖNETIMİ}

Tarihte atık üretmeyen bir toplum ya da kültür olmamasına rağmen sanayi çağından önce, atıkların varlığı insanlar için nadiren endişe yaratmıştır. 19. yüzyıl ve öncesinde hane halkının az atık üretmesi veya atıkların bir endişe kaynağı olmamasının temelinde üretim ve tüketim pratikleri önemli bir unsurdur. O dönemlerde, yemek artıkları çorba yapmak ve hayvan beslemek için kullanılmış, yetişkinlerin ömrünü tamamlayan şeyleri çocuk oyuncağına dönüşmüş, kırılan ürünler tamir edilmiş, mobilya gibi dayanaklı tüketim malları nesilden nesile aktarılmış, tarım ve hayvancılıkta organik gübre kullanılmış, samandan inşaat, eski elbiselerden ise kâğıt yapımında faydalanılmış, sabun üretiminde kemikler, haşere yönetiminde ise kül bir araç olarak öne çıkmıştır. Bu döngü, nüfus artışı, kentleşme ve daha da önemlisi ucuz seri üretimi mümkün kılan montaj hatlarının ortaya çıkmasıyla değişmeye başlamıştır (Mauch, 2016: 5). Başka bir deyişle, Sanayi Devriminden sonra insanlar, büyük miktarda hammadde, doğal kaynak ve enerji kullanarak endüstriyel üretimi ve kentleşmeyi artırmıştır (Lehmann, 2011: 156). Sanayileşme ve kentleşmeye eşlik eden tüketim kültürü, kullanımı kolay, ucuz ve tek kullanımlık ürünleri tercih eden ve kullandıktan sonra onları atan bir toplum yaratmıştır (Mauch, 2016: 5). Bu bağlamda, atık, insanların ihtiyaç duymadığı ya da duymayacağını düşündüğü (Abouelsoud, 2020: 117) ve kullanılmayacağ için elden çıarılmak istenen malzemeleri belirtmektedir (Mishra vd., 2020: 229). Daha geniş bir tanımla atık, fiziki, kimyasal ve bakteriyolojik niteliklerinden ötürü bırakıldıkları ortamların doğal nitelikleri ve kullanım potansiyelini değiştirebilecek, doğrudan ya da dolaylı zarara yol açabilecek, üretim ve tüketim etkinlikleri sonucu ortaya çıkan katı, sıvı, gaz ve atık enerji maddeleridir (Ünal vd., 1998: 11).

Kentleşme, ekonomik gelişme ve nüfus artışının doğal bir sonucu olarak görülen toplam atık miktarı içerisinde katı atıklar önemli bir paya sahiptir. Dünya genelinde, günlük kişi başı ortalama 0,74 kilogram atık üretilmekte ve 2050 yılında ise sadece kentsel katı atık miktarının 3,40 milyar ton olacağ 1 tahmin edilmektedir (Kaza vd., 2018: 17-18). Bu bağlamda, yüzyıllar boyunca döngüsel ekonomi aracılığıyla üretilen atık miktarının azlığı, sanayileşme, kentleşme, nüfus artışı ve tüketim kültürüyle birlikte doğrusal (lineer) bir ekonomiye yönelmiş ve atıkların yönetimi ciddi bir gündem maddesi haline gelmiştir. Büyük miktarlarda atık üretilmesi aynı zamanda, doğal kaynakların yoğun bir şekilde kullanılması ve yok olması tehdidini gündeme getirmiştir (Lehmann, 2011: 156). Atıkların doğal kaynaklar ile çevre ve insan sağ 1 ğı açısından ortaya çıkardığı risklerin minimize edilebilmesi adına bu atıkların etkin bir şekilde yönetilmesi gerekmektedir.

İnsani etkinlikler sonucu ortaya çıkan atıkların yönetilmesi iki açıdan önem taşımaktadır. Birincisi, atıklara ilişkin boşaltma, depolama, arıtma ve bertaraf gibi süreçlerin çevre ve insan sağlığı üzerinde yarattı̆̆ etkilerin ortadan kaldırılması veya en aza indirilmesi; ikincisi ise kıt ve değerli kaynakların 
atık olarak görülmesi sonucu oluşan çevresel kayıpların azaltılması gerekliliğidir (Ewijk ve Stegemann, 2020: 1).

Atık yönetimi, atıkların oluşum sürecinden itibaren, çevrenin, insan sağlığının ve doğal kaynakların korunması amacına yönelen bir kontrol sürecidir (Pongrácz ve Pohjola, 2004: 151). Başka bir ifadeyle atık yönetimi, atıkların üretilmesi, toplanması, işlenmesi, taşınması, bertaraf edilmesi ve atık depolama alanlarındaki tehlikelerin en aza indirilmesine ilişkin süreçlerin bir araya getirilmesidir (Rushton, 2003: 184). 02. 04. 2015 tarih ve 29314 sayılı Resmi Gazetede yayımlanan Atık Yönetimi Yönetmeliğinde, atık yönetimi; "atığın oluşumunun önlenmesi, kaynağında azaltılması, yeniden kullanılması, özelliğine ve türüne göre ayrılması, biriktirilmesi, toplanması, geçici depolanması, taşınması, ara depolanması, geri dönüşümü, enerji geri kazanımı dâhil geri kazanılması, bertarafı, bertaraf işlemleri sonrası izlenmesi, kontrolü ve denetimi faaliyetleri” şeklinde tanımlanmıştır. Bu çerçevede, günümüz atık yönetimi anlayışının, doğrusal ekonomi modelinden ziyade döngüsel ekonomi anlayışına dayandırılmaya çalışıldığı belirtilmelidir.

Doğrusal ekonomi modelinde, üretim ve tüketim süreçlerinin sonucu olarak ortaya çıkan atıklar diğer üretim/tüketim faaliyetlerinde kullanılacak bir kaynak olarak geri kazanılmaz. Atık depolama maliyetlerinin artması ve sıkı çevresel kontroller, toplulukları, sanayi kesimini ve hükümetleri atık yönetim sistemlerini gözden geçirmeye yöneltmektedir. Toplumsal, politik ve yasal düzeylerde, atık üretimi ve bertarafının tek yönlü sürecini yönetmek için geliştirilen altyapının sürdürülebilir olmadığı konusunda giderek artan anlayış ve sürdürülebilir kalkınmanın ekolojik boyutuyla bağlantılı uygulamalara duyulan ihtiyaç doğrultusunda, atık minimizasyonu stratejileri ortaya çıkmaya başlamıştır (Tennant-Wood, 2003: 46). Bir zamanlar sanayi ve topluluklar için yük olarak görülen atıklar, küresel ısınma ve kaynakların tükenmesi gibi çevre sorunlarının etkisini göstermesiyle tutum değişikliği yaratmış ve atıklar toplanması, ayrıştırılması, yönetilmesi ve geri kazanılması gereken değerli bir kaynak olarak tanımlanmaya başlanmışır (Lehmann, 2011: 157). Atık yönetim stratejileri içerisinde atıkların kaynağında azaltılması ve önlenmesi, yeniden kullanılması, geri dönüştürülmesi ve kazanılması gibi uygulamaları öne çıkararak atık miktarının sıfırlanması anlayışına dayanan sıfır atık yaklaşımı günümüzde birçok ülke tarafından benimsenmiştir.

Özetle, kentleşme, sanayileşme, nüfus ve tüketim artışıyla birlikte döngüsel ekonomiden kopmaya başlayan toplumlar büyük miktarlarda atık üretmeye başlamış, üretilen bu atıkların çevre ve insan sağlığına zarar vermeden bertaraf edilmesine yönelik tartışmalar döngüsel ekonomiye tekrardan geçilmesi mantığına dayanan sıfır atık yaklaşımının benimsenmesiyle sonuçlanmıştır. Atıklara yönelik bakış açısının sıfır atık yaklaşımına doğru dönüşmesinde etkili olan birtakım gelişmeler söz konusudur. Bir başka deyişle, sıfır atık yaklaşımını zorunlu kılan birtakım nedenler mevcuttur. 


\section{SIFIR ATIK YAKLAŞIMINI ORTAYA ÇIKARAN NEDENLER}

Sıfır atık yaklaşımına yönelme konusunda toplumları harekete geçiren itici gücü, 20. yüzyılın ikinci yarısından itibaren etkisini hissettirmeye başlayan çevre sorunları ve çözüm önerileri oluşturmaktadır. Bu bağlamda, sıfır atık yaklaşımı, çeşitli üretim ve tüketim faaliyetleri sonucu ortaya çıkan atıkların çevre ve insan sağlığını riske atmadan yönetilmesi anlamına gelmektedir. Sıfır atık düşüncesinin doğuşunun bu genel nedeninin yanında bazı özel nedenlerin olduğu da altı çizilmesi gereken bir noktadır. Murray (1999: 4), sıfır atık yaklaşımının gündeme gelmesini aşağıda verilen üç nedenle açıklamaya çalışır.

- Atık bertaraf sistemlerine ilişkin kaygıların artması,

- Küresel ısınma ve doğal kaynakların tükenmesi gibi global ölçekli çevre sorunlarının ekolojik kaygiları artırması,

- Teknoloji alanındaki ilerlemelerin atık yönetiminde yeni firsatlar yaratması.

Sıfır atık tartışmalarından önce atıklar büyük oranda yakma veya depolama yoluyla bertaraf edilmiştir. Atıkların yakılması, atık miktarını azaltırken kül, gaz ve toksik gaz salınımlarına yol açmaktadır. Depolama ise atıklardan kaynaklı sızıntı sularının toprağa ve suya karışması gibi önemli bir dezavantaja sahiptir (Dileep, 2007: 378). Söz konusu atık yönetim sistemlerinin beraberinde pek çok soruna yol açtığı belirtilmelidir. 1997 yılında Japonya' da yapılan bir araştırma, ülkede bulunan 1.500 atık yakma tesisinin sadece 8 tanesinin dioksin salımının uluslararası standartlarda olduğunu ve bu tesislerden birinin belirlenmiş standartların 10.000 katı salım yaptığını ortaya çıkarmıştır (Murray, 1999: 5). Atık yönetim sistemlerinin yol açtığı çevresel tehditler sadece atıkların yönetilmesi ile ilgili olmamış, aynı zamanda doğal kaynakların yoğun tüketimi de endişeleri artırmıştır. Doğal kaynakların çıkarılması ve işlenmesi enerji gerektirmekte, işlenme süreci ve sonrasında ise büyük miktarlarda atık üretilmekte, toprak ve su kirliliği ile ekosistem tahribatına yol açmakta, küresel 1sınmayı artıracak karbondioksit ve diğer gazların salınımına neden olmaktadır (Connett, 2013: 5). Sadece Amerika Birleşik Devletleri'nde 1900'de 200 milyon ton, 1945'te 600 milyon ton ve 1980’lerde 2,600 milyon ton doğal kaynak tüketilmiştir (Murray, 1999: 6). Doğal kaynakların bu yoğun kullanımının enerji tüketimini artırdığı ve sera gazı salınımlarına neden olduğu gözden kaçırılmamalıdır. Son olarak teknolojik gelişmeler, geri dönüşüm ve geri dönüştürülmüş malzemelerin kullanımı konusundaki yenilikleriyle atıkların üretim ve tüketim süreçlerine birer girdi olarak yansımasına imkân sağlamıştır (Murray, 1999: 6-7). Bu bağlamda döngüsel ekonomi anlayış1 kabul görmeye başlamıştır. Döngüsel ekonomi, bir kişi için kullanım ömrünü tamamlayan ürünlerin, başkaları için kaynağa dönüştürülmesi anlayışına dayanır. Döngüsel ekonomi, doğrusal ekonomi (al, kullan/yap, at) mantığını, yeniden kullanma, yeniden kullanım mümkün değilse geri dönüştürme veya onarma, onarılması mümkün değilse geri kazanılması ve yeniden üretim süreçleri yönünde değiştirilmesi anlayışıdır (Stahel, 2016: 435). 1990'larda çevresel kaygıların odak haline gelmesi ile birlikte, tartışmaların çoğunun atık yönetimiyle bağlantılı olduğu ifade edilmelidir. Sorunların 
çözülebilmesi adına, Almanya 1991'de ambalaj atıklarının azaltılabilmesi için vergileri artırmıs, Danimarka ise atık bertarafına ilişkin vergiler koymuştur. Avrupa Birliği çöp yakma tesislerinin emisyon miktarlarının azaltılabilmesi için radikal önlemler alma yoluna gitmiş ve 1995 'te ambalaj atıklarının azaltılabilmesi amacıyla bir direktif oluşturmuştur (Murray, 1999: 6).

Sıfır atık yaklaşımına giden yolda, yukarıda ele alınan kaygıların yanı sıra, toplam kalite yönetimi anlayışının da etkili olduğu vurgulanmalıdır. Toplam kalite yönetimi anlayışı Amerika Birleşik Devletleri'nde doğmasına rağmen 1950'lerden itibaren Japonya'da uygulanmış ve elde edilen olumlu çıktılarından dolayı 1980'li yıllarda yaygınlaşmaya başlamış bir yönetim felsefesidir (Demirkaya, 2002: 169). Toplam kalite yönetimi, takım çalışması ve grup başarısı için kişisel sorumlulukların yerine getirilmesi, bireysel işlerin kontrol edilmesi, kaliteli ürün üretiminin önemsenmesi, toplumsal sorumluluk, çalışanların sürekli eğitilmesi ve motivasyonlarının artırılması, hataların ayıklanması yerine önlenmesi gibi parametreleri öne çıkaran bir sistem yaklaşımıdır (Barclay, 1993: 89). Toplam kalite yönetiminde üzerinde durulan noktalardan biri olan hataların önlenmesi (sıfır hata-zero defects) anlayışının geniş bir şekilde yorumlanması, özellikle endüstriyel işletmelerin üretim süreçlerinde atık miktarını azaltması veya hiç atık üretmemesi, bir toplumsal sorumluluk olarak kabul edilmiştir. $\mathrm{Bu}$ bağlamda, toplam kalite yönetiminde yer alan sıfır hata anlayışı, sıfır emisyon ${ }^{1}$, çevresel kaliteyi etkileyecek hataların önüne geçilmesi ve enerji israfının durdurularak enerji verimliliğinin artırılması gibi anlamlara sahiptir (Matias ve Coelho, 2011: 902). Başka bir ifadeyle atık yönetimi açısından toplam kalite yönetimi ve sıfır hata anlayışına bakıldığında, şirketlerin/üreticilerin çevresel sorumluluk bağlamında, ortaya çıkardıkları atıkların ekosistemler üzerinde herhangi bir negatif dışsallık oluşturmamasıdır (Welford, 1992: 25).

Connett ve Sheehan (2001: 3), sıfır atık yaklaşımına giden yolda bazı önemli gelişmelerden söz etmektedirler. Bu gelişmelerden ilki, P. Connett'inde aralarında bulunduğu, atıkların depolanarak veya yakılarak bertarafına karşı çıkan teorisyenlerin geri dönüşüm, yeniden kullanım, sürdürülebilirlik ve sıfır atık konularının ele alındığg 1999 tarihli, Sıfır Atık: İdealist Rüya Mı Gerçekçi Hedef Mi? (Zero Waste: Idealistic Dream or Realistic Goal ${ }^{2}$ ) isimli video kaydıdır (Connett ve Sheehan, 2001: 3). Söz konusu video kaydı, bireyleri ve toplulukları atıkların depolanması ve yakılması yoluyla bertaraf edilmesinin tehlikeleri konusunda bilinçlendirmiş ve kişileri bu konuda eylemde bulunması konusunda cesaretlendirmiş, Amerika Birleşik Devletleri’nde yapılması planlanan 300'den fazla çöp yakma tesisinin yapımı bu girişimlerle durdurulmuştur (Connett ve Sheehan, 2001: 3). Sıfır atık yaklaşımına giden yolda yaşanan gelişmelerden ikincisi, Yeni Zelanda'da yer alan belediyelerin \%40'nın 2001'de sıfır atık hedefini benimsemesidir (Connett ve Sheehan, 2001: 3). Üçüncü önemli gelişme, Robin Murray'ın 1999'da tarihli, sıfır atık yaklaşımını ve ekonomik boyutunu ele aldığı Atıktan Zenginlik Yaratmak (Creating Wealth from Waste) isimli

\footnotetext{
${ }^{1}$ Sera gazı salınımı ve atıklardan kaynaklı toksik özelliklerin minimize edilmesine dayanan anlayıştır.

${ }^{2}$ İlgili videoya https://www.youtube.com/watch?v=O_p2dcba_mM adresinden ulaşılabilir. 
kitabıdır (Connett ve Sheehan, 2001: 3). Gelişmelerden dördüncüsü, 2000 yılında başlatılan Slfir Atık Kanada (Target Zero Canada) kampanyasıdır (Connett ve Sheehan, 2001: 4). Beşinci ve son önemli gelişme, Xerox Şirketi Avrupa Ofisi tarafından gerçekleştirilen, eski kopyalama cihazlarının geri kazanılması, onarılması, parçalarının tekrar kullanılması veya başka işlemlerde kullanılacak materyaller olarak geri dönüştürülmesi gibi faaliyetlerden yıllık 76 milyon dolar tasarrufta bulunduğunun tespit edilmesidir (Connett ve Sheehan, 2001: 3-4). Özetle, sıfır atık yaklaşımı, çöplerin yakma ve depolama yoluyla bertaraf edilmesinin sakıncalarının anlaşılması ve atık yönetiminin sürdürülebilir bir boyuta ulaştırılabilmesine ilişkin bilimsel tartışmalarla başlamış, ardından politik ve ekonomik düzeyde kabul edilen bir atık yönetim stratejisi haline dönüşmüştür. Ayrıca, sıfır atık yaklaşımının hem ekonomik hem de çevresel açıdan büyük firsatlar yarattığı belirtilmelidir.

Sıfır atık yaklaşımını ortaya çıkaran nedenler ve kavramın ne ifade ettiğine ilişkin açıklamalar dikkate alındığında, bu yaklaşımın sosyo-politik, çevresel, iktisadi ve teknolojik boyutları içeren çok paydaşlı bir atık yönetim stratejisi olduğu, toplumdaki herkesin atıkları azaltma, yeniden kullanım ve geri dönüşüm gibi uygulamalara sıkıca bağlanması, sıfır atık hedefine ulaşmada önem arz etmektedir (Song vd., 2015: 209).

Toplumları atık ortaya çıkarmayacak üretim ve tüketim kalıpları doğrultusunda dönüştürmeyi amaçlayan sıfır atık yaklaşımının günümüzdeki anlamına kavuşmasında, yaklaşımın geçirdiği tarihsel süreçlerin önemli bir rolü bulunmaktadır.

\section{SIFIR ATIK YAKLAŞIMIN TARİHÇESİ}

Günümüzdeki anlamıyla sıfır atık teriminin ilk kez nerede kullanıldığına ilişkin kesin bir bilgi olmamakla beraber (Snow ve Dickinson, 2003: 4), kavramın ilk defa 1970'lerde Amerikalı kimyager Paul Palmer tarafından kullanıldığı kabul edilmektedir (Warner vd., 2015: 14; Nizar vd., 2018: 3). P. Palmer, Silikon Vadisindeki işletmelerin yeniden kullanılabilecek temiz ve değerli kimyasalları attıklarını fark etmiş, bunun üzerine bu maddelerin ticaretini yapan Slfir Atık Sistemleri Anonim Şirketini 1973'te kurmuş ve kavramın herkes tarafından duyulmasını sağlamıştır (Mauch, 2016: 6; Nizar vd., Warner vd., 2015: 14). P. Palmer'in sıfır atık anlayışı, maddelerin bir kez kullanılması ve atılması yerine, tekrar/yeniden kullanılması ve yakma veya depolamaya alternatif olarak geri kazanılması anlayışına dayanmaktadır (Mauch, 2016: 6). Sıfır atık teriminin günümüzdeki anlamına yakın bir şekilde kullanılması için 1970'li yıllar beklenmiş olmasına rağmen, döngüsel ekonomi ve atıkların işlenerek yeniden kullanılması ve sıfır atık yaklaşımına giden yol ile ilgili görüşlere 19. yüzy1lda rastlamak mümkündür (Antikainen vd., 2018: 116).

P. L. Simmonds, 1862 'de yazdığı, Atık Ürünler ve İşlenmemiş Maddeler: Veya İhmal Edilen Alanlarda Girişimcilik İpuçları (Waste Products and Undeveloped Substances: Or, Hints for Enterprise in Neglected Fields) isimli kitabında, çöp tenekesine atılan elbiselerden kâğıt, kemiklerden el yapımı bıçak, hayvansal yağlardan sabun, yapıştırıcı ve jelatin üretilmesi ile ilgili konuları 
tartışmıştır (Simmonds, 1862). Bu bağlamda, atık sorunu ve atıkların yönetilmesi ile ilgili kaygıların 1860'larda gündem gelmeye başladığı ve günümüzde sıfır atık yaklaşımı olarak nitelenen atık yönetim sistemine doğru evrilmeye başladığı ifade edilmelidir.

George Washington Carver, 1893 yılında yayınlanan makalesinde, doğanın artık/atık materyaller için herhangi bir güç harcamadığını, fakat yaratılan her şeyin büyük bir bütünün vazgeçilmez bir faktörü olduğunu yazmıştır (Ferrel, 2002: 1). Aynı makalesinde G. W. Carver, doğada hiçbir atık materyalin bulunmadığını, yapraktan gübreye kadar pek çok atığın hammadde olarak tekrardan nasıl kullanılabileceğine ilişkin açıklamalarda bulunmuştur (Ferrel, 2002: 1; Yaman ve Olhan, 2010: 5354). G. W. Carver'in düşüncelerinin temelinde, doğada atık hiçbir şey yokken, insanların maddeleri/malzemeleri hiçbir amacı veya değeri yokmuş gibi kullanmaları yer almıştır (Ferrel, 2002: 1). G. W. Carver'in atıklara ilişkin bakış açısı, P. L. Simmonds’a göre daha bütüncül bir çerçeveyi yansıtmaktadır. Endüstride, doğada olduğu gibi, bir süreçten arta kalan atıkların bir diğeri için girdi/kaynak olduğuna ilişkin görüşleri, G. W. Carver'i sadece sıfır atık yaklaşımının öncüleri arasına yerleştirmekle kalmamış, aynı zamanda endüstriyel ve çevresel performanslarını artırmak isteyen işletmelerin bugün endüstriyel ekoloji olarak adlandırdığı akıma da kaynaklık eden görüşler sunmuştur. G. W. Carver, atıklara ilişkin görüşlerini otomobil üreticisi H. Ford'a aktarmış, bunun üzerine H. Ford, otomobil üretiminde kullanılan malzemelerden daha fazla değer yaratmanın yollarını aramıştır. 1930'a gelindiğinde, New York Times'ta yayınlanan bir makalede, Ford'un üretim tesislerinde hiçbir şeyin atılmadığını ve bu yolla yıllık 19 milyon dolar civarında bir tasarruf sağlandığ1 yazılmıştır (Ferrel, 2002: 1-2). G. W. Carver'in atıklarla ilgili görüşlerini endüstri sektöründe başarılı bir şekilde uygulamaya aktaran H. Ford, uygulamalarıyla hem çevre üzerindeki negatif dışsallıklarını azaltmış hem birtakım parasal tasarruflar sağlamış hem de sıfır atık yolunda endüstriyel tasarım ve üretim için bir örnek sunmuştur.

1950'li yıllara gelindiğinde, Japon endüstrisinde uygulanmaya başlayan toplam kalite yönetimi (Demirkaya, 2002: 169) anlayışının sıfır hata düşüncesi, bu üreticilerin sosyal ve çevresel açıdan riski de sıfırlaması olarak düşünülmeye başlanmıştır. 1980'li yıllardan itibaren söz konusu yönetim felsefesi dünyaya yayılmaya başlayınca (Demirkaya, 2002: 169), endüstrilerde atık yönetimi gündeme gelmiştir. 1970’lerde sıfır atık kavramının P. Palmer tarafından kullanıldığı ve toplam kalite yönetimi felsefesinin giderek yaygınlaştığı düşünüldüğünde, sıfır atık anlayışının imalat sektöründe ortaya çıkmasının rastlantı olmadığını gösterecek bir argümandır. Nitekim Toshiba, Toyota, Honda, Nike ve Xerox gibi şirketler sıfır atık hedefi benimsemiş üretici örneklerini oluşturmaktadır (Mauch, 2016: 6; Murray, 2002: 19-20).

1980'li yılların başlarında, Amerika Birleşik Devletleri’nde çöplerin yakılmasının çevre ve insan sağlığı üzerindeki etkilerinin ortaya çıkmasıyla beraber yakma karşıtı eylemler sıfır atık yaklaşımına giden yolda önemli bir mihenk taşıdır. Bu eylemler, 1986' da Büyük Çöp Yakma Tesislerine Karşı ve Güvenli Alternatifler Ulusal Koalisyonunun (The National Coalition Against Mass Burn Incineration 
and for Safe Alternatives) kurulması ile sonuçlanmıştır (Connett, 2013: 44). Koalisyon, yakma tesislerinden kaynaklanan dioksinin çevre ve insan sağlığı üzerindeki etkilerini anlatabilmek için video kayıtları, basılı dökünmanlar ve konferanslar düzenlemiş, çevre ile ilgili sivil toplum kuruluşlarıyla yakın ilişkiler kurmuştur. Ayrıca, koalisyon sadece Amerika Birleşik Devletleri’nde yer alan yakma tesisleriyle ilgili çalışmalar yapmamış, Almanya, Hollanda, Japonya, Fransa, Çin, Avusturya, Belçika ve Hindistan gibi pek çok ülkede yer alan yakma tesisleriyle ilgili çalışmalarda bulunmuştur (Connett, 2013: 43-87). Bu çerçevede, çöplerin yakılarak bertaraf edilmesinin yarattı̆̆ olumsuzluklar ve alternatif arayışlarının, atıkların geri dönüşümü ve yeniden kullanımı gibi uygulamalara yönelmesi, sıfır atık yaklaşımının günümüzdeki anlamına kavuşmasında önemli bir yere sahiptir.

Seattle'da (Amerika Birleşik Devletleri) atı̆̆ın kadar öde (pay as you throw-PAYT) yaklaşımı kapsamında konutlardan geri dönüştürülebilir ve kompostlanabilir malzeme toplanmasına ilişkin düzenleme 1988-1989'da yapılmıştır (Connett, 2013: 301-312). Atığın kadar öde anlayışı, atık hizmetlerinden yararlanan her kullanıcının (gerçek kişi, ticari işletmeler ve tüzel kişiler) ürettiği atık miktarının hacim veya miktarına göre değişken oranlarda ödeme yapmasına dayanan bir sistemdir (Elia vd., 2015: 188). Bu sistemin sıfır atık yönetimine sağladığı en önemli katkılardan biri, atık miktarının kaynakta önlenmesi, azaltılması ve yeniden kullanım ile geri dönüşüm uygulamaları adına gerçek ve tüzel kişiler için ekonomik bir teşvik yaratmasıdır.

1989'da California (Amerika Birleşik Devletleri), entegre atık yönetimi (integrated waste management) yaklaşımına ilişkin yasal süreci tamamlamış ve depolama alanlarındaki atıkların 1995'te \%25'ini, 2000'de ise \%50'sini dönüştürme ${ }^{3}$ hedefi belirlemiştir (Connett, 2013: 301-312). Entegre atık yönetimi, belirli bir yerleşim bölgesi için atık üreticilerinin tamamını kapsayacak şekilde, atıkların kaynakta ayrıştırılması ve azaltılması, yeniden kullanılması ve geri dönüştürülmesi, toplanması, taşınması ve ara depolanması, işlenmesi (geri kazanım, kompostlama ve yakma) ve artık daha fazla faydalanılamayacak atıkların nihai bertarafının sistematik olarak yapıldığı bir süreçtir (Memon, 2010: 31). Entegre katı atık yönetimi, atıkların kaynakta ayrıştırılmasını sağlayarak atıkların kontaminasyonunu azaltıp, geri dönüşüm, geri kazanım ve yeniden kullanım uygulamalarının maliyetlerini düşürmektedir. Buna rağmen, entegre katı atık yönetiminde faydalanılamayacak atıkların düzenli depolama yoluyla bertaraf edilmesi sistemin en önemli dezavantajlarından biridir. Bu dezavantajın ortadan kaldırılabilmesine yönelik uygulamalar, toplumları sıfır atık idealine doğru yöneltmekte ve yaklaştırmaktadır.

1990 yılında T. Lindhqvist İsveç ve diğer ülkelerdeki geri dönüşüm ve atık yönetim sistemleri üzerine yapmış olduğu çalışmalar sonucu, genişletilmişs üretici sorumluluğu (extended producer responsibility) kavramını resmi olarak kullanmıştır (Lindhqvist, 2000). İktisadi İşbirliği ve Gelişme

\footnotetext{
3 Buradaki dönüştürme (diversification) kavramının geri dönüşüm uygulamasıyla karıştırılmaması gerekmektedir.
} 
Teşkilatı (OECD), genişletilmiş üretici sorumluluğunu, üreticinin sorumluluğunun ürünün yaşam döngüsü boyunca ve tüketiciden sonraki aşamayı da kapsayacak şekilde genişletilmesine dayanan çevre politikası yaklaşımı şeklinde tanımlamıştır (OECD, 2001: 9). Genişletilmiş üretici sorumluluğu, imalatçıların ürünün tasarlanmasından, kullanım sonrası bertarafına kadar fiziksel ve/veya mali olarak sorumluluk yüklenmesini sağladığı için üreticilerin ürün tasarımlarını daha az atık ortaya çıkaracak şekilde yapmalarını ve kolayca geri dönüştürülebilir veya kazanılabilir nitelikte imal etmelerini sağlamaktadır.

1996'da Canberra (Avustralya), 2010 yılında sıfır atık hedefine ulaşabilmek amacıyla sıfır atık hedef ve kurallarını yasalaştıran ilk şehir olmuştur (Connett, 2013: 301-312; Nizar vd., 2018: 6). 2004 yılına gelindiğinde Canberra atıklarının \%70'ini dönüştürmeyi başarmıştır (Nizar vd., 2018: 6). 1997'de Yeni Zelanda Sıfır Atık Vakfı (Zero Waste New Zealand Trust) kurulmuş ve vakıf Yeni Zelanda'nın sıfır atık yaklaşımını başaran ilk topluluk olması için bir takım girişimlerde bulunmuştur (TennantWood, 2003: 46; Snow ve Dickinson, 2003: 8). Bu girişimler 2002'de Yeni Zelanda'nın dünyada ilk defa sıfır atık hedefi (2020'de ulaşılması istenmiştir) koyan ülke olmasıyla sonuçlanmıştır (Snow ve Dickinson, 2003: 2).

1997'de California Kaynak Geri Kazanım Birliği (California Resource Recovery Association) sıfır atık konferansı düzenlemiştir. 1998'de Seattle ve Washington gibi Amerika Birleşik Devletleri şehir ve eyaletleri sıfır atık yaklaşımını atık yönetiminin bir ilkesi olarak kabul etmeye başlamıştır (Connett, 2013: 301-312).

2002 yılına gelindiğinde sıfır atık yaklaşımıyla ilgili önemli gelişmeler yaşanmıştır. İlk olarak, dünyada sıfır atık yaklaşımın gelişimine rehberlik edecek standartların oluşturulması amacını taşıyan Uluslararası Sifir Atık Birliği (Zero Waste International Alliance-ZWIA) kurulmuştur (http://zwia.org/zero-waste-definition). İkinci önemli gelişme, dünyada ilk defa sıfır atık hedefi belirleyen ülke unvanına sahip Yeni Zelanda, ilk Sıfır Atık Zirvesine ev sahipliği yapmıştır (Nizar vd., 2018: 4). Aynı yıl yaşanan gelişmelerden üçüncüsü, Robin Murray’ın Sifir Atık (Zero Waste) isimli kitabının yayınlanmasıdır (Connett, 2013: 301-312; Murray, 2002). Dördüncü ve son gelişme, William McDonough ve Michael Braungart'ın Beşikten Beşiğe: Bir Şeyler Yapma Şeklimizi Yeniden Biçimlendirmek (Cradle to Cradle: Remaking The Way We Make Things) isimli kitabın basılmasıdır (Nizar vd., 2018: 4). McDonough ve Braungart (2002), Sanayi Devrimiyle birlikte başlayan beşikten mezara (cradle to grave) şeklindeki tek boyutlu üretim modelinin devasa miktarda atık ve kirlilik yarattığına değinmiş; ömrünü tamamlamış ürünlerin tekrardan yararlı birer eşyaya nasıl dönüştürüleceğine veya atık haline gelen mamullerin başkaları için yeni bir kaynak olarak nasıl kullanılacağını ele almıştır. Bu bağlamda, beşikten beşiğe anlayışı, doğada yüzyıllardır var olan atık üretmeme olgusunun insanlar tarafından taklit edilerek atık ortaya çıkarmamaya ilişkin bir yol haritası sunmaktadır. 
Takvimler 2004 yılını gösterdiğinde, Uluslararası Sıfır Atık Birliği, uluslararası hakemli sıfır atık yaklaşımına ilişkin bir tanımlama yapmış ve söz konusu tanım aynı yöntemle 2009 ve 2018 yıllarında güncellenmiştir. Birliğin hakemli uluslararası sıfır atık tanımları bir arada düşünüldüğünde, sıfır atık, sürdürülebilir doğal çevrimlere özenerek atıkların başkaları tarafından kullanılabilecek birer kaynak olarak tasarlanması, sorumlu üretim ve tüketim kalıplarıyla atıkların yakma/depolama gibi insan ve çevre sağlığını riske atan uygulamalardan kaçınılması yoluyla tüm kaynakların korunmasına yönelik etik, ekonomik, verimli ve vizyoner bir amaç (http://zwia.org/zero-waste-definition) şeklinde dizayn edilmiştir.

2012'de Candida Brady tarafından yazılan ve yönetilen, yapımı Blenheim Films tarafından üstlenilen Çöp (Trashed) adlı belgesel film, Cannes Film Festivalinde ilk kez gösterime girmiştir (Connett, 2013: 301-312; Nizar vd., 2018: 4). Söz konusu belgesel film, mevcut tüketim miktarının ciddi oranda azaltılarak sürdürülebilir bir düzeye getirilmesi ve sıfır atık hedefine ulaşabilmek için nelerin yapılabileceğini gösteren bir eylem çağrısı niteliğindedir.

Sıfır atık ile ilgili yukarıda verilen kronolojik bilgiler ışığında, antropojenik faaliyetlerin geçmişten günümüze ya rastgele ya da düzenli depolama alanlarına yönlendirilen atıkların ortaya çıkmasına yol açtığı görülmüştür (Ayeleru vd., 2018: 87). Bu bağlamda, üretim ve tüketim süreçlerinin tarihin her aşamasında atık ortaya çıkardığı fakat bu atıkların 19. yüzyıla gelene kadar bir sorun olarak görülmediği, 20. ve 21. yüzyılda ise atıkların büyük bir çevresel soruna yol açtığı ve çözülmesi gereken önemli bir problem alanı haline geldiği belirtilmelidir. Yaşanan atık sorununa bir çözüm önerisi perspektifinden, sıfır atık, üretilen atıkların kaynakta önlenmesi, azaltılması, yeniden kullanılması, geri dönüştürülmesi ve kazanılması nosyonu üzerine inşa edilen ve atıkların ortadan kaldırılması yoluna giderek sorunu kökten çözmeyi amaçlayan bir yaklaşımdır.

\section{SIFIR ATIK YAKLAŞIMININ GÜNÜMÜZDEKİ ANLAMI}

19. yüzyılda başlayan atıkların birer kaynak olarak değerlendirilmesi fikrine ilişkin tartışmalara dayandırılabilecek sıfır atık yaklaşımı, günümüzde ulusal, bölgesel ve küresel birçok aktör tarafından farklı şekillerde algılanmakta ve tanımlanmaktadır. Bununla beraber, sıfır atık yaklaşımının temel özeliklerine ilişkin birtakım çıkarımlarda bulunmak mümkündür. 2002 yılında, sıfır atık yaklaşımının gelişimine küresel ölçekte rehberlik edecek standartların oluşturulması amacıyla kurulan Uluslararası Sıfır Atık Birliği, sıfır atık yaklaşımını çeşitli güncellemelerle 2018'de “ürün, ambalaj ve malzemelerin, yakma yoluna gidilmeden, çevre ve insan sağlı̆̆ını tehdit eden toprağa, suya ve havaya bırakılmadan, sorumlu üretim, tüketim, yeniden kullanım ve geri kazanım yoluyla tüm kaynakların korunması" şeklinde tanımlamıştır (http://zwia.org/zero-waste-definition).

Geleneksel atık yönetim sistemlerinde atık, kaynak tüketim sürecinin son aşamasında ortaya çıkan ömrünü tamamlamış ürün olarak kabul edilirken; sıfır atık yaklaşımında atık, kaynak tüketiminin orta aşamasında gerçekleşen ve atığın kaynağa (çeşitli ekonomik faaliyetlerde kullanılabilecek girdiler haline getirilmesi) dönüşümünü ileri süren bir anlayıştır (Uz Zaman, 2014: 682). Atıkların 
yönetilmesi yerine ortadan kaldırılmasını hedefleyen bütüncül bir yaklaşım olmasının yanında sıfır atık, yakma ve depolama yoluyla atıkların bertaraf edilmesinde yaşanan negatif dışsallıkları önleyebilmek için tedarik zincirinin bütün aşamalarında, atıkların kaynağında azaltılması ve ortadan kaldırılmasına dayanan bir tasarım felsefesidir (Curran ve Williams, 2012: 3). Başka bir anlatımla, sıfır atık, toplum tarafından kullanılan malzemelerin döngüsünde büyük bir değişim yaratmayı amaçlayan bütüncül bir sistem yaklaşımıdır. Bu yaklaşım, atıkların ayrıştırılması, yeniden işlenmesi ve kompostlama yollarıyla çeşitli sektörleri destekleyerek, yeni hammadde çıkarma ve işleme ihtiyacını azaltır ve atıklar tüketim malzemeleri yapılmak üzere yeniden kullanılır. Sıfır atık hedefi ve buna eşlik eden sıfır atık modeli, atıkları işleyen mevcut endüstriyel atık sistemini yeniden tasarlar ve atıkların çoğunun depolama alanları ve yakma tesislerine gönderilmesi yerine geri kazanılması esasına dayanır (Edgerly ve Borelli, 2007: 17). Kısaca sıfır atık, atıkların kaynağında azaltılması, atıklar içerisindeki malzemelerin geri kazanılması ve \%100 geri dönüşüm oranının hedeflenmesine dayanan atık yönetim sistemidir (Uz Zaman ve Lehmann, 2011: 77).

Sıfır atık yaklaşımı, doğrusal ekonomi modelinin ürünleri tek sefer kullanıp ardından atılması anlayışının, doğal süreçlerde var olan döngüsel ilişki ile yeniden kurulması mantığına dayanır. Şekil 1, doğrusal ve döngüsel ekonomi modellerini karşılaştırmalı bir biçimde ele almaktadır.

\section{Döngüsel Ekonomi}

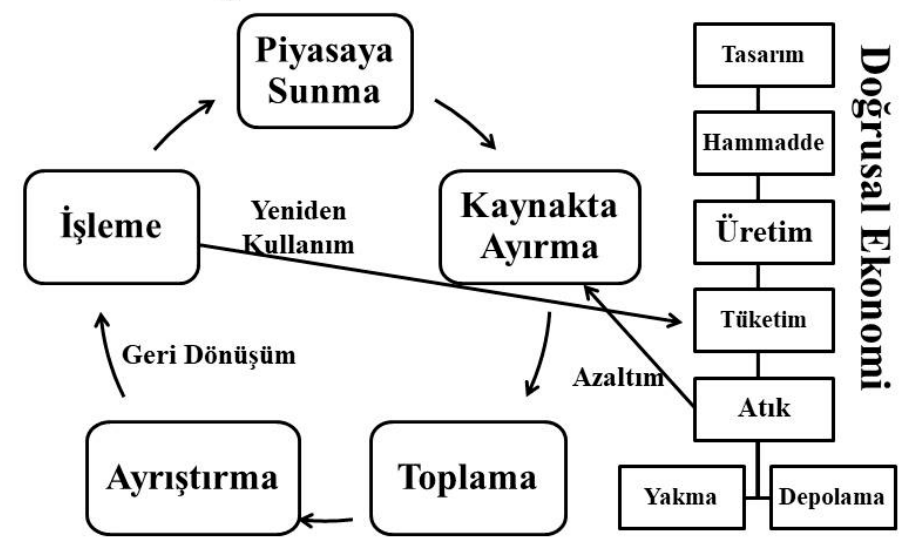

Şekil 1. Doğrusal-Döngüsel Ekonomi

Kaynak: Curran ve Williams (2012: 4); Song vd. (2015: 200).

Şekil 1 incelendiğinde, daha önce de belirtildiği gibi, doğrusal ekonomi modeli, atıkları elden çıkarılacak birer nesne olarak görmekte ve onları yakma ya da depolama yoluyla bertaraf etme yoluna gitmektedir. Buna karşın, döngüsel ekonomi modeli, atık haline gelen ürünlerin toplanması, işlenmesi ve tekrardan piyasaya sunulması anlayışını yansıtır. Nitekim, sıfır atık yaklaşımının temel mantığı olan atıkların kaynağında azaltılması ve yeniden kullanılması, bunun mümkün olmaması durumunda ise atıkların işlenmesi (geri dönüşüm ve kazanım) yoluyla değerlendirilmesi anlayışı döngüsel ekonomi anlayışıyla örtüşmektedir (Song vd., 2015). Bu bağlamda, sıfır atık anlayışı, günümüzde, üretim ve tüketim kalıplarının döngüsel ekonomi modeliyle yeniden buluşturulması anlamına gelmektedir. 
Sıfır atık idealine ulaşılabilmesi için, atıkların yönetilmesi sürecinde, en çok tercih edilecek yöntemlerin en üstte, en az tercih edilecek yöntemlerin ise en altta bulunduğu atık hiyerarşileri önemli bir rehber niteliğindedir (Gharfalkar vd., 2015: 305). Şekil 2'de sıfır atık hiyerarşisi sunulmuştur.

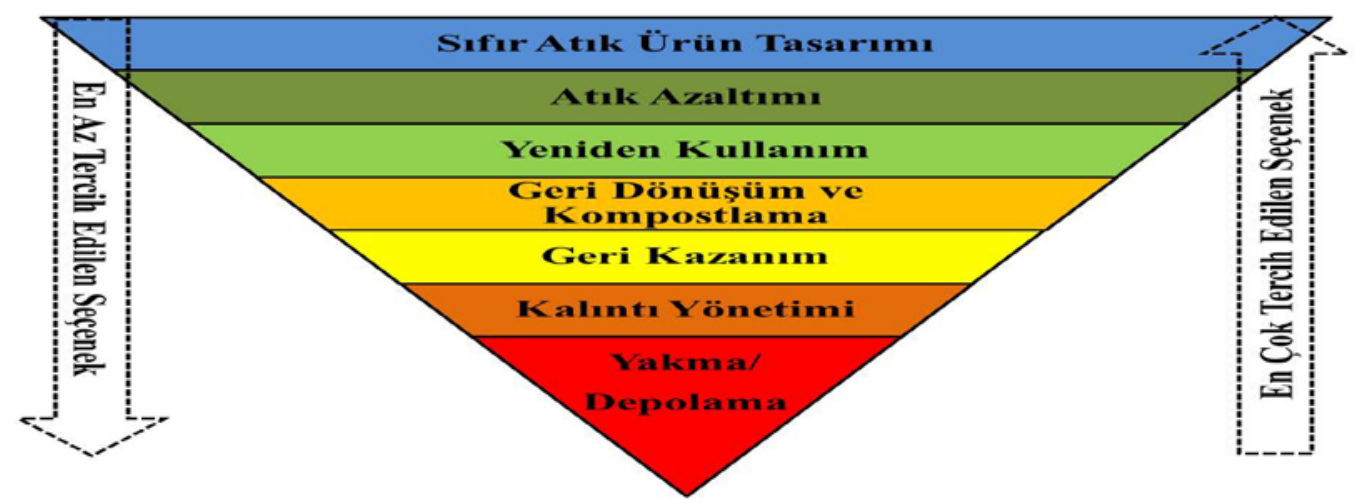

Şekil 2. Sıfır Atık Hiyerarşisi

Kaynak: Simon (2019) ve ZWIA (2018)'den türetilmiştir.

Sıfır atık hiyerarşisi (Şekil 2), atığın kaynakta önlenmesi, yeniden kullanılması ve atıkların azaltılmasını önceleyen, yakma yoluyla enerji kazanma yolunu ise başta dioksin emisyonlarını artırarak çevre ve insan sağlığına verdiği zararlardan dolayı en son seçenek olarak görüldüğü bir anlayışı yansıtmaktadır. Sıfır atık hiyerarşisinin ilk adımı olan sıfır atık ürün tasarımı, ürün ömrünün uzatılabilmesi adına, tamir edilebilme, yeniden kullanıma uygunluk ve ikincil bir ürün imalatı için kaynak olarak yararlanılmaya elverişlilik özelliklerini ön plana çıkarır. Aksi takdirde, atığın çevreyi kirletmeden geri dönüşümü, kazanımı ve doğal süreçlerle kolayca beslenmesi sağlanmalıdır (Uz Zaman, 2014: 683; Kahraman ve Sarı, 2017: 16). Atıkların azaltılması ve yeniden kullanımı ise, atığın miktar, hacim ve toksik özelliklerinin azaltılması; atık haline gelen ürünün aynı ya da benzer amaçlarla doğrudan yeniden kullanımın sağlanmasını ifade eder (ZWIA, 2018). Geri dönüşüm; atıkların hammadde/kaynak olarak imalat etkinliklerinde yeniden kullanılmas1; kompostlama ise atıklar içerisindeki organik maddelerin mikroorganizmalar tarafından ayrıştırılmasıdır (Tchobanoglous vd., 2002: 1.8-1.11). Geri kazanım, karışık halde bulunan atıklardan üretim/tüketim süreçlerinde kullanılmak üzere ikame malzemelerin hazır hale getirilmesidir (Çevre ve Şehircilik Bakanlığı. 2014: 6). Kalıntı yönetimi, atıkların işlenmesinden sonra değerlendirilemeyen atıkların, incelenmesi ve azaltılmasının yollarının aranması, atıklardan daha fazla faydalanma yöntemlerinin ve mevcut atık depolama sistemlerinin faydasını maksimize etmeye yönelik araştırmaların yapılmasına ilişkin süreçlerdir. Sıfır atık yaklaşımında, yakma yoluyla atıklardan enerji üretilmesi veya atıkların düzenli depolanması en son hatta istenmeyen seçenek olarak değerlendirilir ve bu aşamada, tercih edilen yöntemlere yönelebilmek için yeni politikaların aranması istenir (ZWIA, 2018; Simon, 2019). Günümüzde sıfır atık yaklaşımı, öncelikle imalat sürecinden başlanarak ürünlerin atık ortaya çıkarmayacak veya yeniden kullanılabilecek şekilde tasarlanması ve atık miktarının kaynakta azaltılması, ürünlerin yeniden kullanılması, bunun mümkün olmaması durumunda geri 
dönüştürülmesi ve/veya kazanılması, yakma ve depolama alternatiflerinin atık yönetim süreçlerinden çıkarılmak istendiği bir atık yönetim stratejisini yansıtmaktadır.

\section{SONUÇ}

Dünya nüfusunun günümüze oranla az ve ihtiyaçların karşılanması için yapılan üretim ve tüketim faaliyetlerinin doğayla uyumlu olduğu 19. yüzyıla kadarki dönemlerde, atıklar büyük bir sorun teşkil etmemiştir. 19. yüzyıldan itibaren üretilen atıklar, önemli ve acilen çözülmesi gereken bir problem alanı haline gelmiştir. Yaşanan atık probleminin temelinde, sanayileşme, kentleşme, nüfus artışı ve doğrusal ekonomi modeline (al-kullan-at) dayanan üretim ve tüketim kalıpları yer almıştır. Atık sorununun çevre ve insan sağlığını tehdit edecek düzeylere ulaşmasıyla beraber çözüm arayışları da başlamıştır. İlk başlarda, atıkların yaşam alanlarından uzaklaştırılması, atıkların yakma yoluyla hacim ve miktarının azaltılması ve enerji elde edilmesi ile atıkların düzenli/düzensiz depolanmasına yönelik çeşitli politikalar tercih edilmiştir. Söz konusu yöntemlerin her birinin birtakım dezavantajlara sahip olması (örneğin atıkların yakılmasının toksik gaz salınımını artırıcı etkide bulunması) atık üretimini azaltacak ve/veya ortadan kaldıracak çözümlere ihtiyaç duyulduğunu göstermiştir. Bu çözüm arayışları içerisinde, doğal çevrimlerle büyük oranda benzerlik gösteren döngüsel ekonomi anlayışı ön plana çıkmıştır. Döngüsel ekonomi anlayışındaki, herhangi bir kişi için ömrünü tamamlamış bir ürünün, bir başkası için kaynak olabileceğine ilişkin görüş, atıkların yakılarak veya depolanarak bertaraf edilmesi yönteminin sorgulanmasına ve atıkların birer girdi haline dönüştürülmesinin yollarının aranmasına kaynaklık etmiştir.

Atıkların istenmeyen ve ortadan kaldırılması gereken maddeler değil, bir kaynak olduğuna ilişkin düşünceler, günümüzde sıfır atık olarak nitelenen atık yönetim stratejisinin gelişmesinde büyük öneme sahiptir. Atıkların kaynakta azaltılması, ayrıştırılması, yeniden kullanımı, geri dönüşümü ve kazanımı uygulamalarının benimsendiği; yakma ve depolama gibi atık bertaraf yöntemlerinin çevre ve insan sağlığı açısından taşıdığı risklerden dolayı tercih edilmemesi gereken bir anlayışı yansıtan sıfır atık yaklaşımının günümüzdeki anlamına kavuşana değin geçirdiği tarihsel bir gelişim süreci söz konusudur.

Atıkların bir kaynak olarak yeniden kullanılmasına ilişkin görüşlerle 19. yüzyılda karşılaşılmıştır. Bu dönemde P. L. Simmonds (1862) ve G. W. Carver (1893) gibi isimler, atıkların, doğal süreçlerde olduğu gibi, birer girdi olarak nasıl kullanılabileceğine ilişkin fikirler beyan etmiştir (Antikainen vd., 2018: 116; Ferrel, 2002: 1-3). G. W. Carver'in görüşleri, otomobil üreticisi H. Ford tarafından üretim süreçlerinde uygulanmış ve önemli tasarruflar sağlanmıştır. Toplam kalite yönetimi anlayışının sıfır hata anlayışı, firmaların atıklarını çevresel ve toplumsal sorumluluk bağlamında görmeleri fikrinin doğmasına yol açmıştır. 1970'li yıllara gelindiğinde sıfır atık kavramı P. Palmer tarafından ilk kez kullanılmıştır (Warner vd., 2015: 14). Atıkların yakılarak bertaraf edilmesinin ortaya çıkardığı riskler, 1980'lerde bu yönteme karşı eleştirel ve alternatifler öneren bir yaklaşımın doğmasına neden olmuştur. Tarih 1990'ları gösterdiğinde, devlet ve kent yönetimleri sıfır atık hedef ve uygulamaları 
belirlemeye başlamıştır. Takvimler 2000'li yıllara geldiğinde Uluslararası Sıfır Atık Birliğinin kurulması, pek çok ülkenin (örnek: Avustralya, Yeni Zelanda, İtalya, Kanada, ve İrlanda) sıfır atık hedefi belirlemesi, sıfır atık zirve ve konferanslarının gerçekleştirilmesi, sıfır atıkla ilgili yayınların artması ve sıfır atıkla ilgili belgesel filmin gösterime girmesi gibi pek çok gelişme yaşanmıştır. Bu gelişmeler sadece atık sorununa dikkat çekmekle kalmamış, aynı zamanda atık ortaya çıkarmayan bir ekonomik ve toplumsal yapıya geçişi hedefleyen sıfır atık yaklaşımının günümüzdeki anlamına kavuşmasını da sağlamıştır.

Sıfır atık yaklaşımı günümüzde döngüsel ekonomi modeli ve atık hiyerarşileri bağlamında ele alınmaktadır. Döngüsel ekonomi modeli, atıkların üretim ve tüketim süreçlerinde birer girdi olarak yararlanılmasının kuramsal yapısını oluşturmaktadır. Atık hiyerarşileri ise atık yönetiminde öncelikli uygulamaların neler olması gerektiğinin tespit edilmesini sağlamaktadır. Tarihsel gelişmelerin birikimiyle günümüzde sıfır atık yaklaşımının taşıdığı anlam, ürünlerin atık ortaya çıkarmayacak biçimde tasarlanması, atığın kaynakta azaltılması, yeniden kullanılması, geri dönüştürülmesi ve kazanılması yollarını önceleyen ve nihayetinde ortaya çıkan atıkların tamamının bir kaynak olarak tekrardan kullanılmasını sağlayacak yöntemlerin arandığı bir atık yönetim stratejisini ifade etmektedir.

Son olarak, 19. yüzyıldan itibaren karşılaşılan atık sorununun çözümü için geliştirilen sıfır atık yaklaşımına ilişkin politikalar belirlenirken önceliğin atıkların kaynakta azaltılması ve önlenmesine, daha sonra geri dönüşüm ve kazanım uygulamalarına gidilmesinin çevresel açıdan daha optimal bir çözüm sunacağı vurgulanmalıdır. 


\section{KAYNAKÇA}

Abouelsoud, A. M. (2020). Waste design using experimental design techniques. Journal of Design Science and Applied Arts, 1(1), 116-124. https://doi: 10.21608/jdsaa.2020.70457

Antikainen, R., Lazarevic, D. \& Seppala, J. (2018). Circular economy: Origins and future orientations. In Lehmann, H. (Eds.), Factor X: Challenges, implementation strategies and examples for a sustainable use of natural resources (pp.115-130). Cham: Springer. https://doi.org/10.1007/978-3-319-50079-9_7

Atık Yönetimi Yönetmeliği (Tarih: 02. 04. 2015, Resmi Gazete Sayısı: 29314).

Ayeleru, O. O., Okonta, F. N. \& Ntuli, F. (2018). Municipal solid waste generation and characterization in the City of Johannesburg: A pathway for the implementation of zero waste. Waste Management, 79, 87-97. https://doi.org/10.1016/j.wasman.2018.07.026

Barclay, C. (1993). Quality Strategy and TQM Policies: Empirical Evidence. MIR: Management International Review, 33, 87-98.

Connett, P. \& Sheehan, B. (2001). A citizens agenda for zero waste: A United States/Canadian perspective. GrassRoots Recycling Network, https://archive.grrn.org/zerowaste/community/activist/citizens_agenda_2_read.pdf (E. T. 31.07.2020).

Connett, P. (2013). The zero waste solution: Untrashing the planet one community at a time. Vermont: Chelsea Green Publishing.

Curran, T. \& Williams, I. D. (2012). A zero waste vision for industrial networks in Europe. Journal of Hazardous Materials, 207-208, 3-7. https://doi.org/10.1016/j.jhazmat.2011.07.122

Çevre ve Şehircilik Bakanlığı. (2014). Düzenli depolama tesisleri saha yönetimi ve işletme kılavuzu. https://webdosya.csb.gov.tr/db/destek/editordosya/Duzenli__Depolama__ Tesis _Saha_Yon_ve_isletme_kilavuzu.pdf (E. T. 20/07/2020).

Demirkaya, H. (2002). Toplam kalite yönetimi felsefesinin siyasette uygulanabilirliği. Süleyman Demirel Üniversitesi İktisadi ve İdari Bilimler Fakültesi Dergisi, 7(2), 169-187.

Dileep, M. R. (2007). Tourism and waste management: A review of implementation of 'zero waste' at Kovalam. Asia Pacific Journal of Tourism Research, 12(4), 377-392. https://doi.org/10.1080/10941660701823314

Edgerly, J. \& Borrelli, D. (2007). Moving toward zero from waste management to resource recovery. Montpelier: Toxic Action Center.

Elia, V., Gnoni, M. G. \& Tornese, F. (2015). Designing pay-as-you-throw schemes in municipal waste management services: A holistic approach. Waste Management, 44, 188-195. https://doi.org/10.1016/j.wasman.2015.07.040

Ewijk, S. \& Stegemann, J. A. (2020). Recognising waste use potential to achieve a circular economy. Waste Management, 105, 1-7. https://doi.org/10.1016/j.wasman.2020.01.019

Ferrel, J. (2002). George Washington Carver and Henry Ford: Pioneers of zero waste. http://www.zerowaste.org/publications/PIONEERS.PDF (E. T. 31.07.2020).

Gharfalkar, M., Court, R., Campbell, C., Ali, Z. \& Hillier, G. (2015). Analysis of waste hierarchy in the European Waste Directive 2008/98/EC. Waste Management, 39, 305-313. https://doi.org/10.1016/j.wasman.2015.02.007

http://zwia.org/zero-waste-definition/ (E. T. 28.07.2020)

Kahraman, C. \& Sar1, İ. U. (2017). Introduction to Intelligence Techniques in Environmental Management. In Kahraman C., \& Sari İ. (Eds), Intelligence Systems in Environmental Management: Theory and Applications (pp. 1-18). Cham: Springer. https://doi.org/10.1007/9783-319-42993-9_1 
Kaza, S., Yao, C., Bhada-Tata, P. \& Woerden, F. (2018). What a waste 2.0 A global snapshot solid waste management to 2050. Washington DC: World Bank Group.

Lehmann, S. (2011). Optimizing urban material flows and waste streams in urban development through principles of zero waste and sustainable consumption. Sustainability, 3, 155-183. https://doi.org/10.3390/su3010155

Lindhqvist, T. (2000). Extended producer responsibility in cleaner production: policy principle to promote environmental improvements of product systems. Lund University.

Matias, J. C. O. \& Coelho, D. A. (2011). Integrated total quality management: Beyond zero defects theory and towards innovation. Total Quality Management \& Business Excellence, 22 (8), 891910. https://doi.org/10.1080/14783363.2011.593862

Mauch, C. (2016). Introduction: The call for zero waste. Mauch, C. (Eds), A Future Without Waste? Zero Waste in Theory and Practice (pp. 5-12). Munich: Rachel Carson Center Perspectives.

McDonough, W. \& Braungart, M. (2002). Cradle to cradle: Remaking the way we make things. New York: North Point Press.

Memon, M. A. (2010). Integrated solid waste management based on the 3R approach. Journal of Material Cycles and Waste Management, 12, 30-40. https://doi.org/10.1007/s10163-009-0274-0

Mishra, K., Banerjee, A., Ranga, M. M., Jhariya, M. K., Yadav, D. K. \& Raj, A. (2020). Solid waste management scenario in Ambikapur, Surguja, Chhattisgrah: A sustainable approach. In Raj, A., Jhariya, M. K., Yadav, D. K. \& Banerjee, A. (Eds.), Climate Change and Agroforestry Systems; Adoptation and Mitigation Strategies (pp. 297-336). Ontario-Florida: Apple Academic Press.

Murray, R. (1999). Creating wealth from waste. London: DEMOS.

Murray, R. (2002). Zero waste. London: Greenpeace Environmental Trust.

Nizar, M., Munir, E., Munavar, E. \& Irvan, M. (2018). Implementation of zero waste concept in waste management of Banda Aceh City. Journal of Physics: Conference Series, 1116, 1-12. https://doi:10.1088/1742-6596/1116/5/052045

OECD. (2001). Extended producer responsibility a guidance manuel for governments. Paris: OECD Publications Service.

Pongrácz, E. \& Pohjola, V. J. (2004). Re-defining waste, the concept of ownership and the role of waste management. Resources, Conservation and Recycling, 40, 141-153. https://doi.org/10.1016/S0921-3449(03)00057-0

Rushton, L. (2003). Health hazards and waste management. British Medical Bulletin, 68, 183-197. https://doi.org/10.1093/bmb/ldg034

Simmonds, P. L. (1862). Waste products and undeveloped substances: Or, hints for enterprise in neglected fields. London: Robert Hardwicke.

Simon, J. M. (2019). A zero waste hierarchy for Europe new tools for new times: From waste management to resource management. https://zerowasteeurope.eu/2019/05/a-zero-wastehierarchy-for-europe/ (E. T. 26.08.2020).

Snow, W. \& Dickinson, J. (2003). Getting there! The road to zero waste. Auckland: Envision New Zealand Ltd.

Song, Q., Li, J. \& Zeng, X. (2015). Minimizing the increasing solid waste through zero waste strategy. Journal of Cleaner Production, 104, 199-210. https://doi.org/10.1016/j.jclepro.2014.08.027

Stahel, W. R. (2016). Circular economy. Nature, 531(March), 435-438.

Tchobanoglous, G., Kreith, F. \& Williams, M. E. (2002). Introduction, waste generation and management in a technological society. In Tchobanoglous, G \& Kreith, F (Eds.), Handbook of Solid Waste Management (pp. 1.1-1.27). Second Edition, McGraw-Hill Handbooks. 
Tennant-Wood, R. (2003). Going for zero: A comperative critical analysis of zero waste events in Southern New South Wales. Australasian Journal of Environmental Management, 10(1), 46-55. https://doi.org/10.1080/14486563.2003.10648572

Uz Zaman, A. \& Lehmann, S. (2011). Challenges and opportunities in transforming a city into a zero waste city. Challenges, 2, 73-93. https://doi.org/10.3390/challe2040073

Uz Zaman, A. (2014). Identification of key assessment indicators of the zero waste managament systems. Ecological Indicators, 36, 682-693. https://doi.org/10.1016/j.ecolind.2013.09.024

Uz Zaman, A. (2015). A comprehensive review of the development of zero waste management: Lessons learned and guidelines. Journal of Clenaer Production, 91, 12-25. https://doi.org/10.1016/j.jclepro.2014.12.013

Ünal, E., Duyguluer, F., \& Bolat, E. Z. (1998). Imar terimleri. Ankara: Yorum Matbaas1.

Warner, C., Phillips, P., Santos, A. \& Pimenta, B. (2015). Evaluation of zero waste places projects 2009-2010 in England. Proceedings of the Institution of Civil Engineers-Waste and Resource Management, 168(1), 14-25. https://doi.org/10.1680/warm.13.00014

Welford, R. (1992). Linking quality and the environment: A Strategy for the implementation of environmental management systems. Business Strategy and The Environment, 1(1), 25-34. https://doi.org/10.1002/bse.3280010105

Yaman, K. \& Olhan, E. (2010). Atık yönetiminde sıfır atık yaklaşımı ve bu anlayışa küresel bir bakış. Biyoloji Bilimleri Araştırma Dergisi, 3(1), 53-57.

ZWIA. (2018). Zero waste hierarchy of highest and best use 7.0. http://zwia.org/zwh/ (E. T. 26.08.2020). 